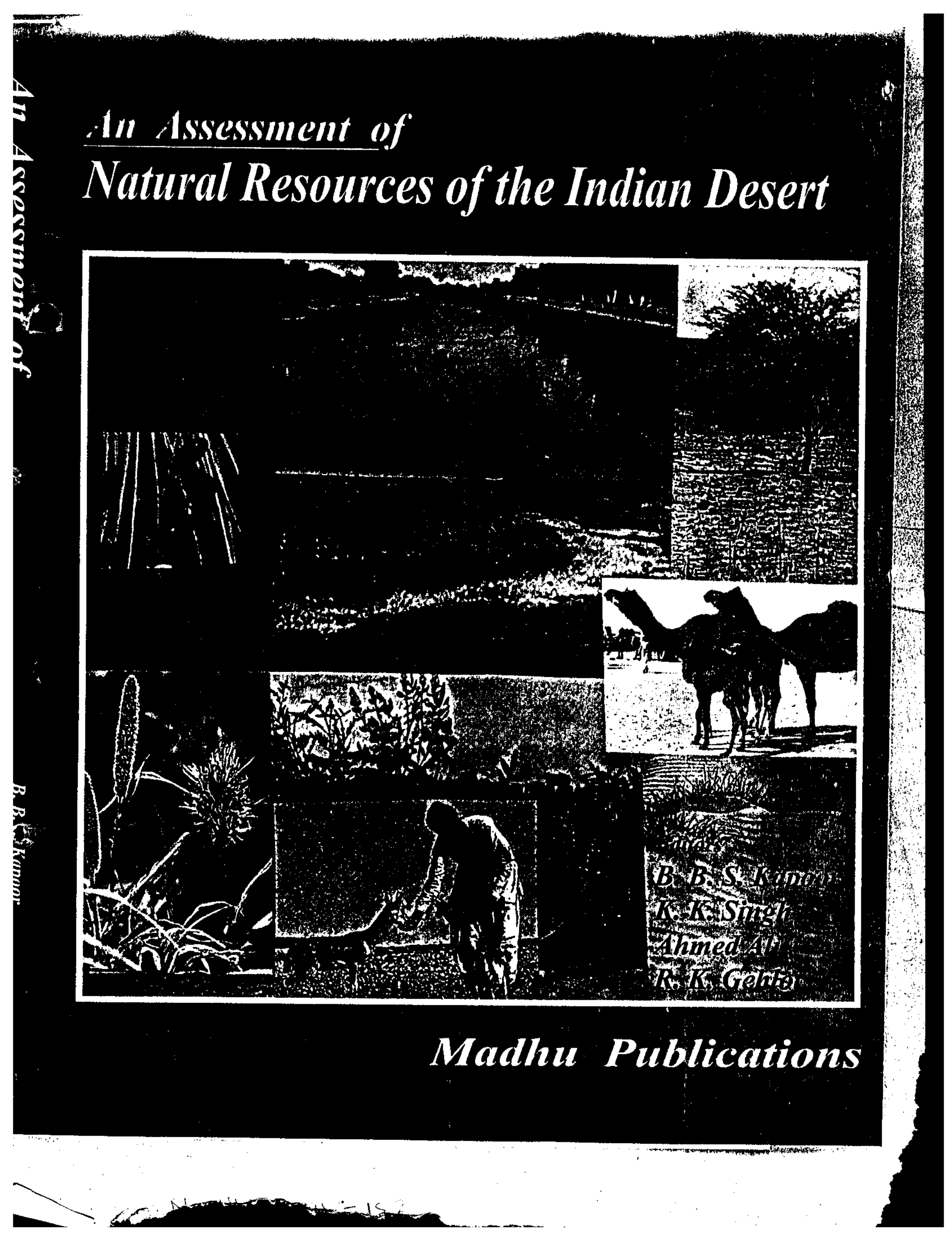




\title{
WORK POTENTIAL OF CANEL UNDER ARID ECO-SYSTEM AND ITS MANAGEMENT
}

\author{
S. RAGHVENDAR, CHAMPAK BHAKAT AND M.S. SAHANI
}

In India, arid zone covers about $12 \%$ of country's geographical area and occupies over lion $\mathrm{km}^{2}$, hot desert located in parts of Rajasthan $(6.1 \%)$, Gujarat (20\%), Punjab and Haryana (9\%) and Andhra Pradesh and Karnataka (10\%) (Shankaranarayan, 1987). Animal husbandry under such degraded land can be successful only if the live stock are basically a stable protective resource having long term viability, employment absorbing capability and income . Generating capacity. The livestock should be compatible with crop cultivation and natural vegetal resources available instead of competing with it for land and water resource. Camel rearing enterprise suits well with such conditions. The abbresiation of 'CAMEL' may be expanded as H' $C$ '- carrier, 'A'- Arid Zone, ' $M$ '- multipurpose, ' $E$ '- Eco-friendly and ' $L$ '- Livestock. Their Fitity to survive long period under hot dry climate without water is legendary. Through ages, the \& Latomy and physiology of camel has evolved mechanisms to combat the hostile environment of F ise desert, to thrive on scanty food, to dissipate body heat and to survive without water for long periods. Modified structure of the four stomachs, ability to digest coarse vegetation, rise in body temperature, passing of concentrate urine and nearly dry facces are some fine examples (Yagil, 1985 and Rai et al., 1995).

The total world population is estimated to be 19.6 million of which India has third highest camel population of 1.52 million (FAO, 1998) after Somalia and Sudan. Indian camel population is mainly confined to north-western states viz.: Rajasthan, Gujarat, Haryana and Punjab (93.12\% of total Indian camel population) with density of camel in eleven arid district of Rajasthan (70.13\% of total Indian camel population) (Khanna et al., 1990).

\section{EL WORK POTENTIAL}

The camel is a very versatile working animal suitable for variety of functions including uat pulling, drawing wheels, ploughing, sugar cane crushers, oil mills, carrying water, transport of unan in agricultural operations under arid and semi-arid zones. The camel as provider of tonomic resource of bio-energy is very widely utilized and is not only cast effective for short istance transportation but also profitable and remunerable. Camel work potential is influenced various factors viz. breed, age, sex, body conformation, training, season, terrain, pay-load, amess and implements and riders/driver.

$$
\begin{aligned}
& \text { PUBLISHED IN BOOK "AN ASSESSMENT OF NATURAL } \\
& \text { RESOURCES OF THE INDIAN DESERT" (MADHU PUBLICATION) }
\end{aligned}
$$




\section{DRAUGHT CAPACITY}

Podberezkin (1951) reported that two bactrian camels when yoked together could pois $1400 \mathrm{~kg}$ while Mathanu (1996) studied that the Indian camel could produce draught power equal 2 ponies and could pull cart with 1 tone load. An Indian canel could pull $816 \mathrm{~kg}$ weight properly harnessed cart (Singh, 1963), Knoess (1976) studied that camels have better outiog potential than cattle. Dong Wie (1979) reported that the bactrian camel can pull one tore for which is equivalent to the capacity of Chinese ponies or 2 oxen. Rai and Raghvendar lad studied that Indian camel could haul 1.5 to 2 tons for 4-6 hour covering a distance of 30-40 (1990) two and four wheel cart without showing signs of distress. It can work for $4 \mathrm{hr}$ at a stretch om reduces $\mathrm{hr}$ rest in between. The speed, draught force, work performance and stretch and 6 hours covithe increase in distance covered. The Indian camel could have 15 power out put hours covering distance of 20 to $30 \mathrm{Km}$ on 2 and 4 wheel carts The draught force generated by a camel ranges from $90-125 \mathrm{~kg}$ aut showing signs of distreax weight. The tractive force $(\mathrm{N})$ and work done $(\mathrm{KJ} / \mathrm{Kg})$ at $2 . \mathrm{kg}$ amounting to $17-22 \%$ of bot distance of $22 \mathrm{~km}$ was 586 to 791 and 1.54 to 170 ) at $2.8 \mathrm{~kg} / \mathrm{kg}$ body weight pay load upto generated from 0.93 to 1.27 . On the basis of blood physioly. The horse power (hp) pas indicators, it was observed that four wheel cart is better thysiological and biochemical fatigie

er than Jaisalmeri and Kachchhi for endurance for draun two wheel cart. Bikaneri camels are positrively riding/race. Heart girth, height at wither and body weight and lengri breed perform sufficient ofter 15 wour horse power and draught. The work rest cycle indicated 2 cr. rest are sufficient after $4-5$ hours continuous work. The indices for formust cycle indicated $2 \mathrm{hr}$. rest to be been identified.

A pilot survey was carried out on comparative study of camel used for drough

Bikaner cily and surrounding village area. The majo agricultural operation, water carrying and breeding etc uses of camel is in carting along The people engaged in this vocation were mainly land lessending upon season and requirement are used to transport variety of items viz. material with in the city. Maximum male camels wand, gas cylinder, food grains and building carting is estimated to be higher (approx. Rs. $6000-7000$ per carting. The income from came village area (approx. Rs. 4000-5000 per month).

\section{PLOUGHING CAPACITY}

Nanlda (1975) studied that camel is capable of ploughing of ap has been recommended not to work fol is capable of ploughing of approximately $2.5 \mathrm{~km} / \mathrm{hr}$ and hp energy during plough covering for longer than 6 hours at stretch. Camel can produce up 16" (Knoess, 1976). Rai and Khanna 11 hours and could plough $500 \mathrm{M}^{2} /$ hour at a depther continuously for $4.25 \pm 0.27 \mathrm{hr}$ and covera (1991) showed that dromedary camels could plowt $\%$ of body weight the horse power generated area of $3136 \pm 168 \mathrm{M}^{2}$. The draught produced $\mathrm{k}_{\mathrm{b}}$ oods weight was found to be $523 \pm 0.37 \mathrm{sqm}$.

\section{RDING AND BAGGAGE POTENTIAL}

The characteristics of good riding camel are long legs, display boldness, alert expresine symentrical hump, broad muscular full thighs, small-sized foot-pads and strong knees joits
Matharu (1966) recommended that animals carrying load of $180 \mathrm{~kg}$ should be worked for 8 hit only at the speed of 3.2 to $4.8 \mathrm{~km} / \mathrm{hr}$ and distance covered should should be worked for 8 hith, 


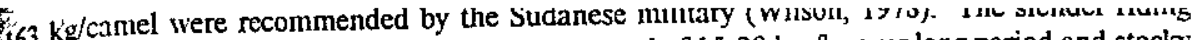
camel cain cover up to $100 \mathrm{~km} /$ day at an average speed of $15-20 \mathrm{~km} / \mathrm{hr}$ over long period and stocky pack dromedary can cover 20 to $25 \mathrm{~km} /$ day at an average speed of about $5 \mathrm{~km} / \mathrm{hr}$ and can carty burden of $200 \mathrm{~kg}$ on its back (Burgemeister, 1978). Dina and Klinteberg (1977) studied that African camel is capable on traveling @ $10 \mathrm{~km} / \mathrm{hr}$ and may cover about $48 \mathrm{~km}$ in a day with pack load of $54 \mathrm{~kg}$ along with rider! Williamson and Payne (1978) studied that a load of 159 to $295 \mathrm{~kg}$ could be carried by a baggage camel on its back over an indefinite period while about $544 \mathrm{~kg}$ mar be carried for shorter distance. Khanna and Rai (1994) reported that the camels traveled $950 \mathrm{~km}$ in 29 days and covered distance ranging from 24 to $70 \mathrm{~km} /$ day at an average of $43.2 \mathrm{~km} /$ day in a camel safari across the desert of Rajasthan, India. Raghvendar et al. (1998) studied that the riding camels were targeted to complete $15 \mathrm{~km}$ at a stretch at the speed of $8-9 \mathrm{~km} / \mathrm{hr}$. The level of lactate and cortisol in the riding camels indicated better riding endurance in females than male Indian camels.

\section{RACING POTENTIAL}

Since ancient times, camels have been recorded as playing an integral role in the daik of the people of Asia and Africa. Camel racing in the Gulf and certain Arabian countries is an rant cultural event which emphasize the Bedouin traditions of animal husbandry skills. hospitality and competitions. Yousef et al. (1989) observed that camels had a lower than expected oxygen uptake $\left(\mathrm{VO}_{2}\right)$ during both rest and walking exercise $(1 \mathrm{~m} / \mathrm{sec})$. The camel with its low $\mathrm{VO}^{2}$ max but with a capacity to exercise at relatively high speed $(9.0-10.0 \mathrm{~m} / \mathrm{sec})$ for prolonged periods, similar to the horse. The maximum values of $55-56 \mathrm{ml} / \mathrm{kg} / \mathrm{min}$ have recorded in the current study are the same as those in the steer (Jones et al., 1989). The maximal $\mathrm{O}_{2}$-pulse normalized for body weight is above $0.6 \mathrm{mi} / \mathrm{beat} / \mathrm{kg}$ in the horse and dog but only $0.3 \mathrm{ml} / \mathrm{beat} / \mathrm{kg}$ in the camel. Evans and Rose (1988) reported that with maximal heart rates (HR max), the maximum stroke volume in the camel which is a slightly lower maximum stroke volume than found in horses. The oxygen cost of transport per $\mathrm{km}$ traveled in $50 \%$ of the cost compared to the horse. The long limb length enabled the pacing gait to the maintained even at high speeds. This gait would therefore appear to allow grater mechanical efficiency and therefore speeds around 9$10 \mathrm{M} / \mathrm{Sec}$ to be maintained despite relatively low oxygen availability. Raghvendar and Sahani (1999) reported better race potential in Jaisalmeri than Bikaneri female camels. Average race speed $(\mathrm{km} / \mathrm{hr})$ for 1,2 and $3 \mathrm{~km}$ distances were ranged from $29 \pm 2.6$ to $37 \pm 3.2$ and $25 \pm 3.2$ to $30 \pm 1.8$ for Jaisalmeri and Bikaneri Indian female camels respectively. The maximum race speed of female and male Jaisalmeri and Bikaneri during $3 \mathrm{~km}$ race was recorded as 29.4, 28.4, 24.4 and $27.9 \mathrm{~km} / \mathrm{hr}$ respectively.

\section{USE IN DEFENCE}

The role of camel in defence is very well evidenced from the ancient and during the firs second world war by camel battalion in arid region. The camels formed important component ur army during Maurya period (AC 322-232 BC) and continued through middle ages (Mughal (period 1200-1700 AD) to the present times. The famous Ganga-Risala of the erstwhile Bikaner state was accepted and as Imperial service troop and participated in world war I and II. In independent India, the Ganga Jaisalmer Risala was constituted in 1948. In 1954, this corps formed part of 13 , Graneders Regiment. Presently the camel corps constitutes an important wing of the border security force of the Indian Para Military services and used for petrolling purpose in cesert boarder belt 


\section{CAMEL MANAGEMENT PRACTICES}

The camel was domesticated more recently than other animals. The most probable pefiof of domestication of camel is prior to $1800 \mathrm{BC}$. The methods of camel keeping are now changing world wide because the grazing land is decreasing as more land is put under cultivation reducing the free grazing land. Camels which are largely maintaincd under extensive system are now facing problem and their management needed a better alternite system which is socially acceptable and economically viable.

\section{CANEL MANAGEMENT BY RATKAS}

The recent camel management by Rikas are extremely diverse, varying from free ranging for most of the year at one extreme to continuous closely supenised herding at the other. The ecological setting and the degree of competition from other land use strategies determine which particular herding system if adhered to it. In the extremely arid sparsely populated most western parts of Rajastlian, where hardly any agriculture if practiced, camels can be left to themselves for mortof the year. Many of them return at regular intervals to the villages for water, but they can al he several hundred $\mathrm{km}$ from their owners home. The Raikas are able to keep track of their movements bccause they can identify the footprints of cach of their camels.

\section{CAMEL MANAGEMENT BY EXTENSIVE SYSTEM}

In this system camels are allowed to graze freely and reproduces freely. All the camels are collectcd once every usually in the spring season for wool shearing treatment against mange branding ctc. The animals are released far free grazing again after above operations. It is usually necessany to collect camel herds during the 3 months of the rainy season (July to September) to - prevent them from danaging crops. Most, but not all herders also like to supervise their camels during the breeding season which traditionally falls between the two Hindu festivals of Diwali (around November) and Holi (around March) in order to prevent fights between competing males.

\section{CAMEL MANAGEMENT BY SEMI-EXTENSIVE SYSTEM}

In this system camels are maintained around citics and villages in the marginal area and feeding is practiced. During severe drought period camels have been fed special feed lots for 24 months, during this period daily gain are expected to be satisfactory.

\section{FEEDING MANAGEMENT}

Camel mostly get feed from trees bushes and rarely from grasses. In stall feeding tions the average feed consumption is maximum in the initial 2 hrs which decreased subsequently. The camel continued to consume feed during nights hrs and eat $38.5 \%$ of total feed consumption during night along.

The average daily feed consumption during day time ranged from $5.92 \pm 0.46 \mathrm{~kg}$ to 7.25 $\pm 0.11 \mathrm{~kg}$ per day. The average feed consumption during night ranged from $5.00 \pm 0.10 \mathrm{~kg}$ to 6.0. $\pm 0.29 \mathrm{~kg}$ per day. The average period of pasture grazing varied from $6.25 \pm 0.43$ to $10.54 \pm 0.31$ hour per day. The frequency of watering is twice in summer and once daily during winter rainy season. 


\section{MANGER}

1 A manger about $90-120 \mathrm{~cm}$ high is constructed. A square pillare about $92 \mathrm{~cm}$ height erected and over it, a platform of about $70 \mathrm{~cm} \times 70 \mathrm{~cm}$ is constructed and a wall of 15 is thickness is built on all the four sides of it from 30 to $45 \mathrm{~cm}$ height. This is box like mang without lid.

\section{OTHER TYPES OF MANGER}

The cheapest type is constructed by i) digging a pit in the ground of about $50-70$ diameter and $50 \mathrm{~cm}$ deep, ii) the manger is made up of kachcha bricks or mud and cow dun $\mathrm{cm}$ pucca bricks.

\section{CAMEL HEALTH MANAGEMENT}

There is a large body of ethno-veterinary knowledge on the camel derived from generations of interaction and interdependence with this animals. Even, today camel from rely have access to modern veterinary core. They continue to rely on their oun system of case prophylaxis, diagnosis and treatment.

\section{INDIGENOUS KNOWLEDGE OF CAMEL HEALTH}

Camel farmers have long recognized the Effectiveness of many range plant substan treatment of discase. These includes several herbs, roots, seeds ctc. Indian medicine for treatment of human being. venomous action of biting insects and animg. They have identificd plants which detoxify the plants which have hormone like activities arc live scorpions, snakes and flying insects. Some are used a glactogogues for lacto stimulation and characteristics in treatment of infections, antiviral and antiprotozoal activitics. Along thenc parasites, fungal skin diseases, oral diseases; and hematic parasites e.g. trypanosome the same times plants extracts active for phagocytosis knowledge of poisonous plants and thcir antite used. In addition, camel keepers have detailed preparations and solution of salts. The antitodes which include drenching of infusions of plant accessible to the camel keepers.

In an organised farm (NRRC), the camel are provided both propl vitamins-A. A course of antibiotics is given paries and pregnant females are given control with traditional antianhoea. Mange can be brought under imsive. However, trypanosoctions, even if these methods are time consuming and labour

tional treatment are in use, buts is a disease which defeats indigenous methods. A variety of

\section{CONCLUSION}

Camel is a wonderful animal to sustain high temperature and is equipped with mechanism to retain and dissipate heat without affecting the vital systems. Camel can also
withstand dehydration by nobilizing internal avoiding water losses as far as possible and repleninshing water resources, conserving body watch of water within minutes. Following and repleninshing water loss by consuming huge quantifif 
flowly in 3 to 4 days to keep it as reserve for future nceds. It is infact an ideal draught animal baving strength and ability to cover long distance with minimum of food and water in arid zone Fivand has enormous power endurance and hardiness. The training of young camel for tiding, cart pulling algricultural operations should be impoarted by camel herd men who are specialized in this trade. Camel (Camielus dromedarious) constitute an important component of the desert ecosystem beciuse of its adaptation in an anatomical, behavioral and physiological functions. Rapid change in agro-ecological conditions and industrialization in recent past has its negative impact on camel traditional management practices. It is essential in future to adopt scientific management practices to get efficient utilization of camel work potential round the year for different operations.

\section{REFERENCES}

Burgemeister, R. (1978). Distribution and use of dromedaried. Animal Reseanth and Development. 7; 39-48.

Dina, D. and Klinterberg. R. (1977). Proposal for rural development training project and study concerned with arrel utilization in arid lands in Ethopia. Relief and Rehabilitation commission Addis tbaba.

Dof (1979). Chinese camel and their productivities. Workshop on camels, Khartoum, December, 1979. IFS provisionai report No.6.

Evens, D.L. and Rose, R.J. (1988). Cordiovascular and respiratory responses to exercise in thorough bred horse. J. ExpBiol. 134: 397,408

FAO (1998). Production Year Bouk, Rome, Italy.

Jones, J.H., Longworth, K.E., Lintholm, A, Copley, K.E., Kara, R.H.; K.yyar, S.R. and Taylor, C.R (1989). Os:5 transport during exercise in large manmals. J. Appl. Physiology, 67: 862-870.

Khanna, N.D. Rai. A.K. and Shama, N. (1996). Camel safari. Drought Animal News, 24, 13-! 5.

Rhanna, N.D., Rai. AK., T:Indon, S.N. (1990). Population trends and distribution of camel population of lndia, Iafing Joumal of aunal sciences. 60(3): $331-337$.

Knoess, K. (1976). Evoluating periomance and management of Adual Camel. In assignment report on Arion Production in the middle, awash Valley.

Kohler-Rollefson, 1. (1994). Camel pastoratism: An indigenous arid hrod explanation strategy. J. camel. Pract. Res. I il: $1-6$.

Matharu, B.S. (1996), Camel carc. Indian Farming. 16(17): 19-22.

-

Nanda, P.N. (1957). The camel and their management. Indian council of Agricultural Research, New Delhi, India, 17.

i.:.

Podberezkin Ja. (1995). Experience of the work of a better camel breeding from Korevodstro, 10: 42-43.

3 dar,

S., Rai. A.K., Sahani, M.S. and Khanna, N.D. (1998). Comparative study on riding performance of male ant female camels. Proceeding of third Annual Meeting for Animal production under Arid conditions, 1: 126-130. United Arab Emirates University, U.A.E.

Ragivendar, S. and Sahani, M.S. (2000). Evaluation of race potential using physiological and biochemical tools in ferel: racing camels. Annual Report, NRCC, Bikaner, India : 7.9.

Rai, A.K and Raghvendar, S. (1976). Investigation of a fatigue index in Indian camel. Draught Animal News. 24. 11-13.

造

A., Khanna N.D. and Roy, A.K (1991). Endurance for ploughing and fatigue. Annual Report (1990-91), NRCC. Bikaner. India : 7.8 . 

Raj, AK, Naga, AK and Thana, N.D. (1995). Effect of water restriction on nutrient utilization in pack camel ba
hot humid condition, Indian Journal of Animal Science, 65(1 I): $1256-1265$.

Shankarnarayan, K_A (1987). Arid Zone Management, "An era of self sufficiency in food productions", L.C.A.R, Ne. Delhi, India, 181-193.

Williamson, G. and Payne, W.J.A. (1978). An Introduction to animal husbendary in the Tropics. Zrdiedn. Topical scion in Agriculture, Longan, London.

Wilson, RT. (1978) Studies on the livestock of southern Darfur, Sudan V. Notes on carnet Tropical Animal Health production, 10. 19-25. Hunting Technical Services Ltd, Barchan word, United Kingdom

Wilson, R.T. (1985). The Camel, Longan, London, 223.

Yagil, R. (1985). The Desert Camel, Karyer, Based, 163.

Yousef, M.K, Webster, M.E.D. and Yousef, O.M (1989). Energy costs of walking in camel, Camelus dromedaries Physio Zool. 62: 1080-1088. 